\title{
Esophageal Stricture Prevention after Endoscopic Submucosal Dissection
}

\author{
Deepanshu Jain ${ }^{1}$ and Shashideep Singhal ${ }^{2}$ \\ ${ }^{1}$ Department of Internal Medicine, Albert Einstein Medical Center, Philadelphia, PA, ${ }^{2}$ Division of Gastroenterology, Hepatology and Nutrition, \\ University of Texas Health Science Center at Houston, Houston, TX, USA
}

Advances in diagnostic modalities and improvement in surveillance programs for Barrett esophagus has resulted in an increase in the incidence of superficial esophageal cancers (SECs). SEC, due to their limited metastatic potential, are amenable to non-invasive treatment modalities. Endoscopic ultrasound, endoscopic mucosal resection, and endoscopic submucosal dissection (ESD) are some of the new modalities that gastroenterologists have used over the last decade to diagnose and treat SEC. However, esophageal stricture (ES) is a very common complication and a major cause of morbidity post-ESD. In the past few years, there has been a tremendous effort to reduce the incidence of ES among patients undergoing ESD. Steroids have shown the most consistent results over time with minimal complications although the preferred mode of delivery is debatable, with both systemic and local therapy having pros and cons for specific subgroups of patients. Newer modalities such as esophageal stents, autologous cell sheet transplantation, polyglycolic acid, and tranilast have shown promising results but the depth of experience with these methods is still limited. We have summarized case reports, prospective single center studies, and randomized controlled trials describing the various methods intended to reduce the incidence of ES after ESD. Indications, techniques, outcomes, limitations, and reported complications are discussed.

Clin Endosc 2016;49:241-256

Key Words: Esophageal neoplasms; Esophageal stenosis; Endoscopic submucosal dissection

\section{INTRODUCTION}

In 2015 13,570 men and 3,410 women in the United States are expected to be newly diagnosed with esophageal cancer (EC). ${ }^{1}$ Although EC accounts for only $1 \%$ of newly diagnosed cancers in the United States, it is much more prevalent in Iran, northern China, India, and southern Africa. ${ }^{1}$ Based on the National Cancer Institute's Surveillance, Epidemiology, and End Results (SEER) database, the 5-year survival rate for localized, regional, and distant EC is $40 \%, 21 \%$, and $4 \%$, respectively. ${ }^{2}$

Received: August 4, 2015 Revised: September 16, 2015

Accepted: October 14, 2015

Correspondence: Shashideep Singhal

Division of Gastroenterology, Hepatology and Nutrition, University of Texas Health Science Center at Houston, 6431 Fannin, MSB 4.234, Houston, TX 77030, USA

Tel: +1-713-500-6677, Fax: +1-713-500-6699, E-mail: sdsinghal@gmail.com

(cc) This is an Open Access article distributed under the terms of the Creative Commons Attribution Non-Commercial License (http://creativecommons.org/ licenses/by-nc/3.0) which permits unrestricted non-commercial use, distribution, and reproduction in any medium, provided the original work is properly cited.
With advancements in diagnostic technology and active surveillance programs for patients with Barrett esophagus, more cases of EC are being diagnosed in their early stages. Superficial esophageal cancer (SEC) is a term used to represent ECs limited to the mucosa with minimum metastatic potential, and they are thus amenable to non-surgical treatment options. Endoscopic modality has evolved as the preferred diagnostic and therapeutic treatment choice for these SECs. Endoscopic ultrasound offers an accuracy of 85\% in diagnosing SEC. ${ }^{3}$ Endoscopic mucosal resection (EMR) is an alternative modality to stage SEC. In the last decade, there has been a gradual shift of focus from EMR to endoscopic submucosal dissection (ESD) for SEC. ESD allows en bloc resection of the lesion irrespective of its size and is associated with a lower recurrence rate as compared to EMR, which essentially involves piecemeal resection of lesions more than $2 \mathrm{~cm}$ in size. ${ }^{4}$

Esophageal stricture (ES) is the most common complication following ESD. ${ }^{5}$ Histologic depth and circumferential extension of the EC are independent risk factors for post-operative 
C clinical endoscopy

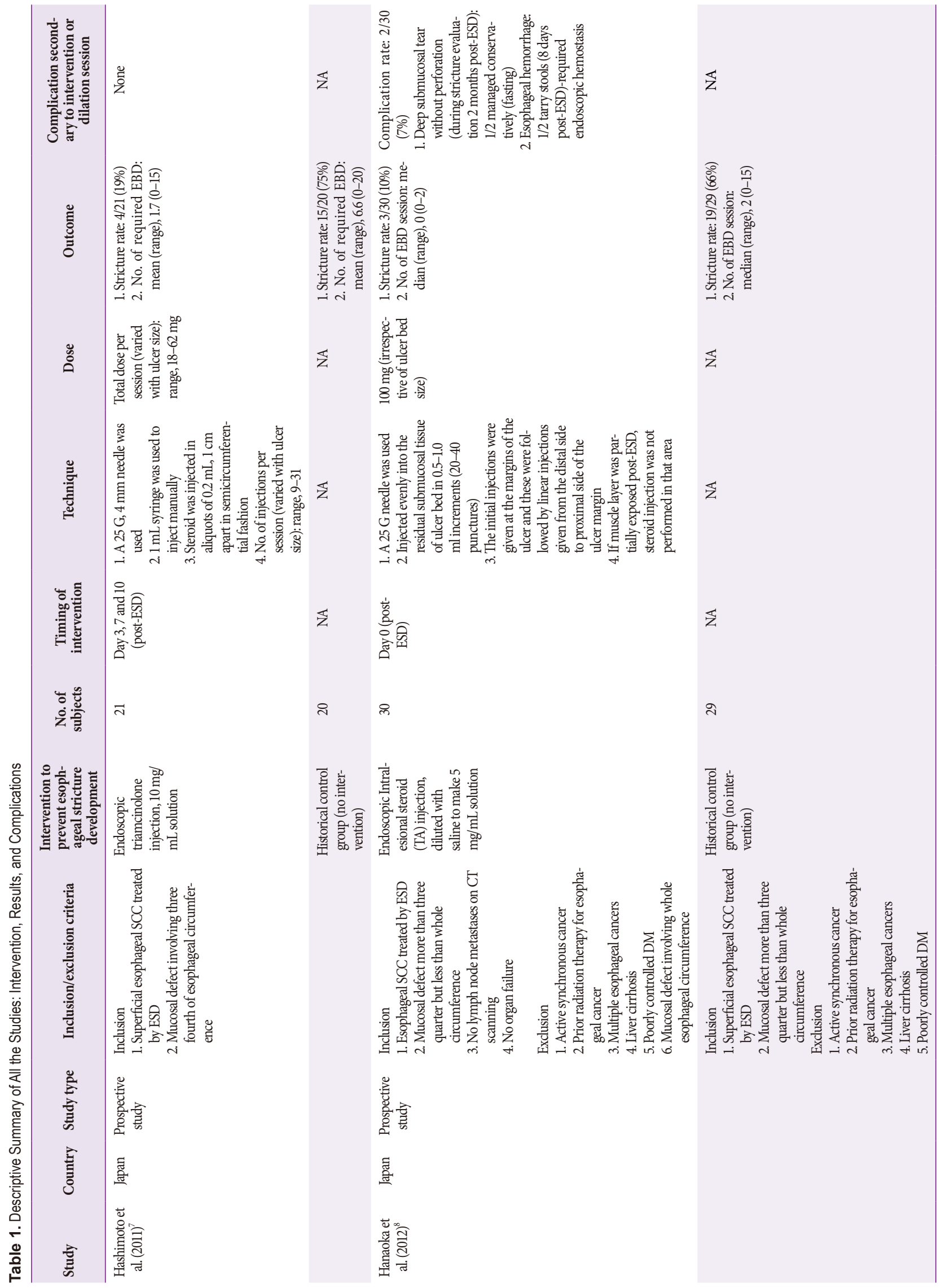




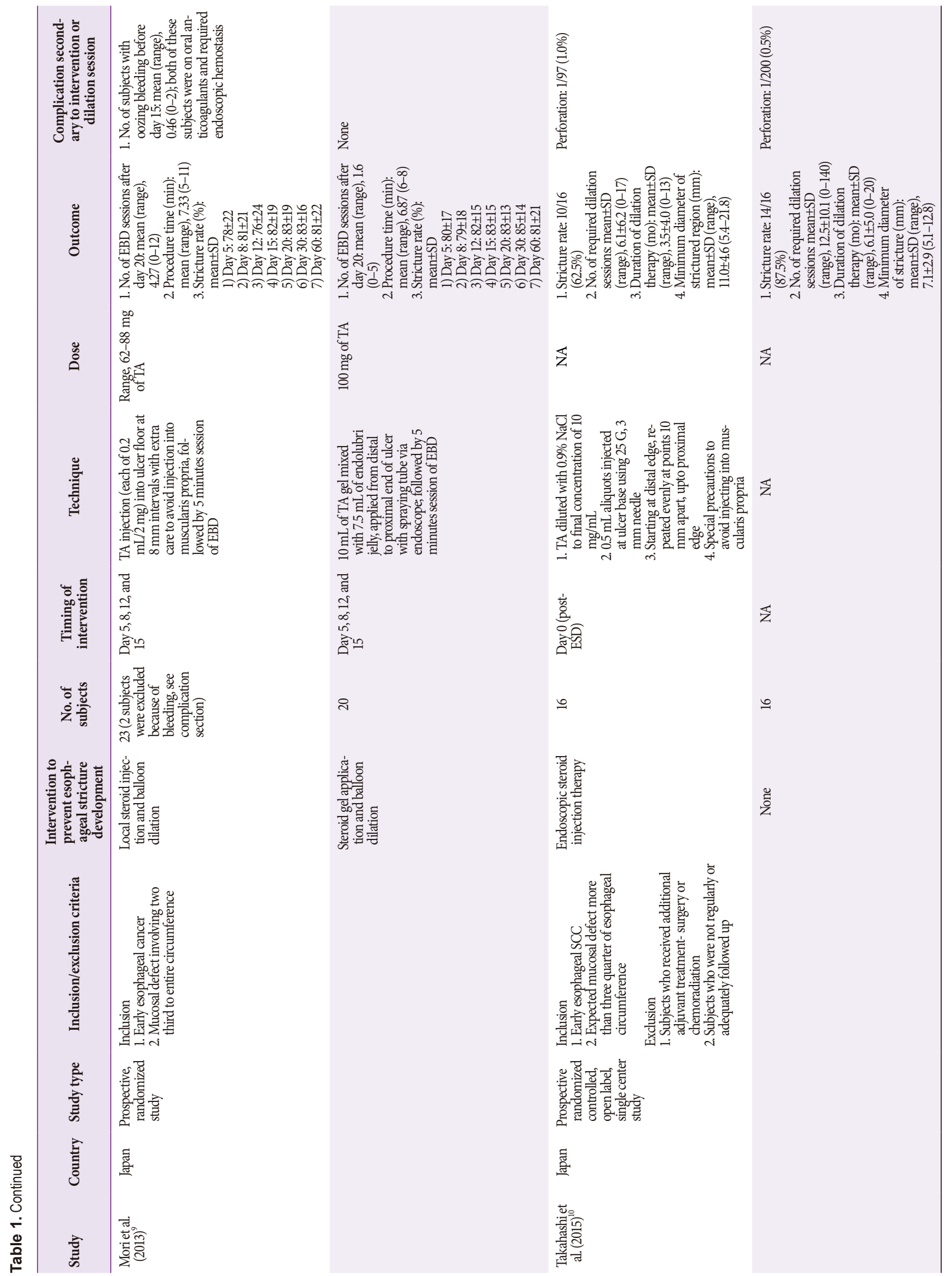




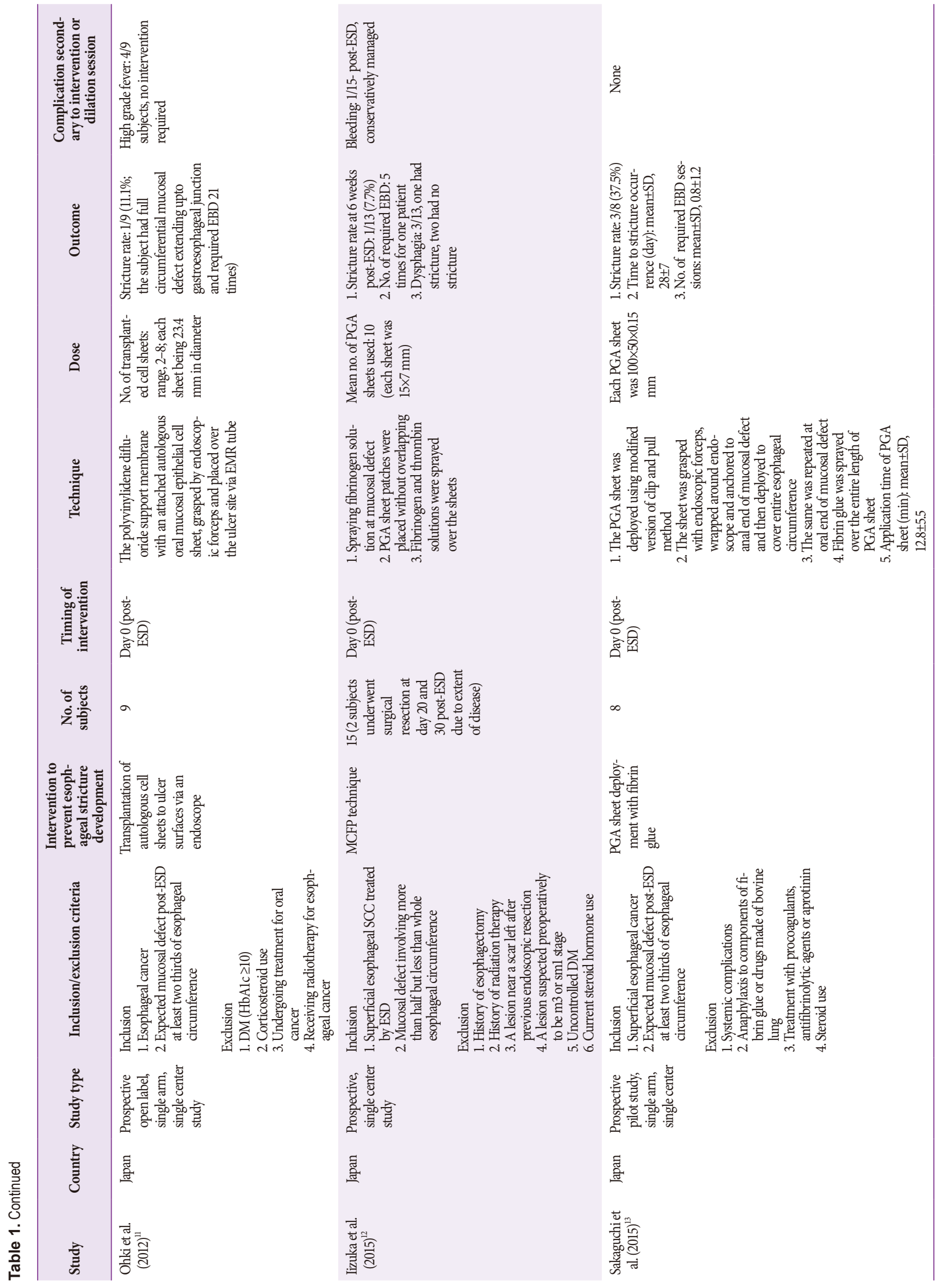




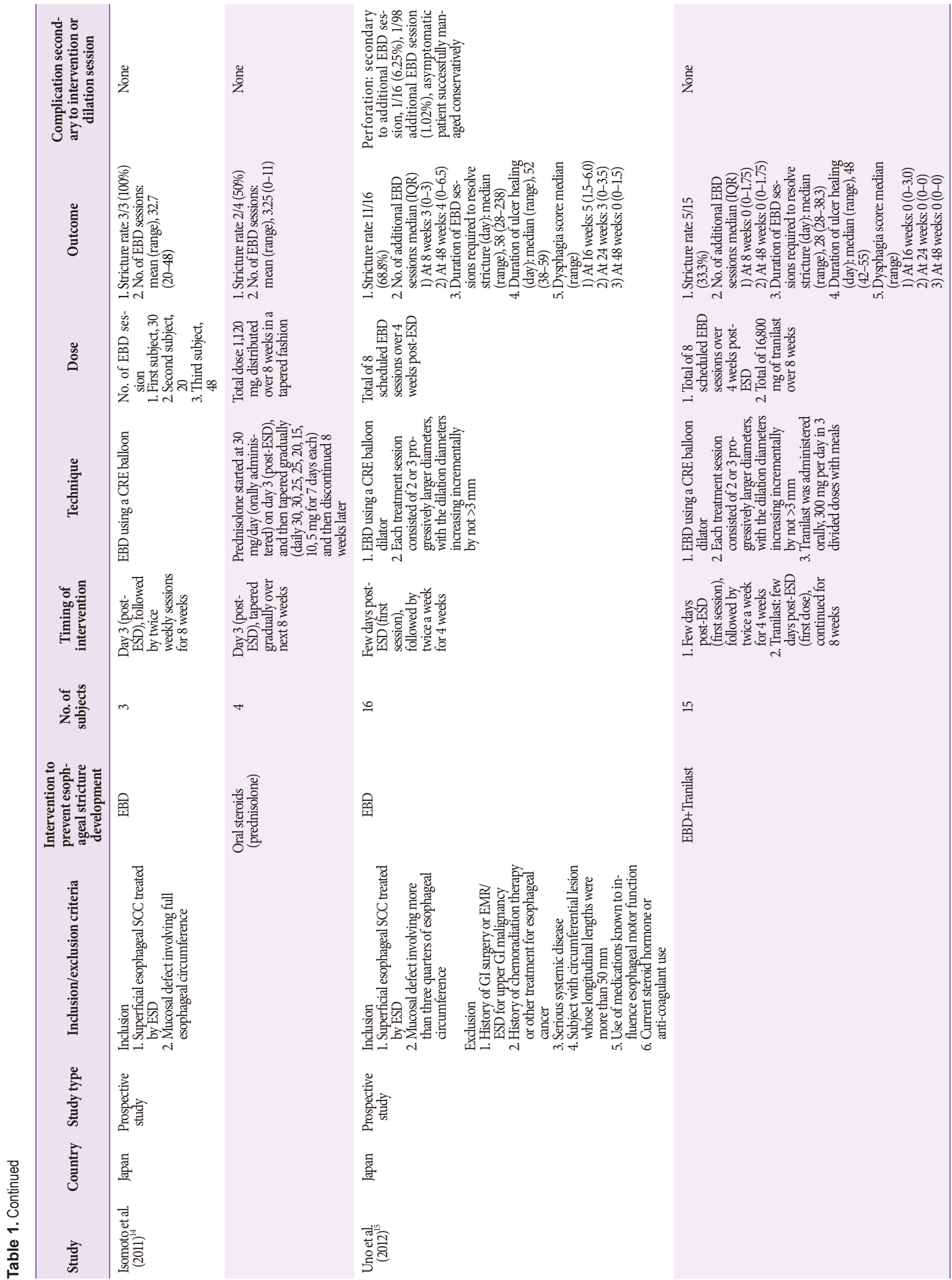


C cunical endoscopy

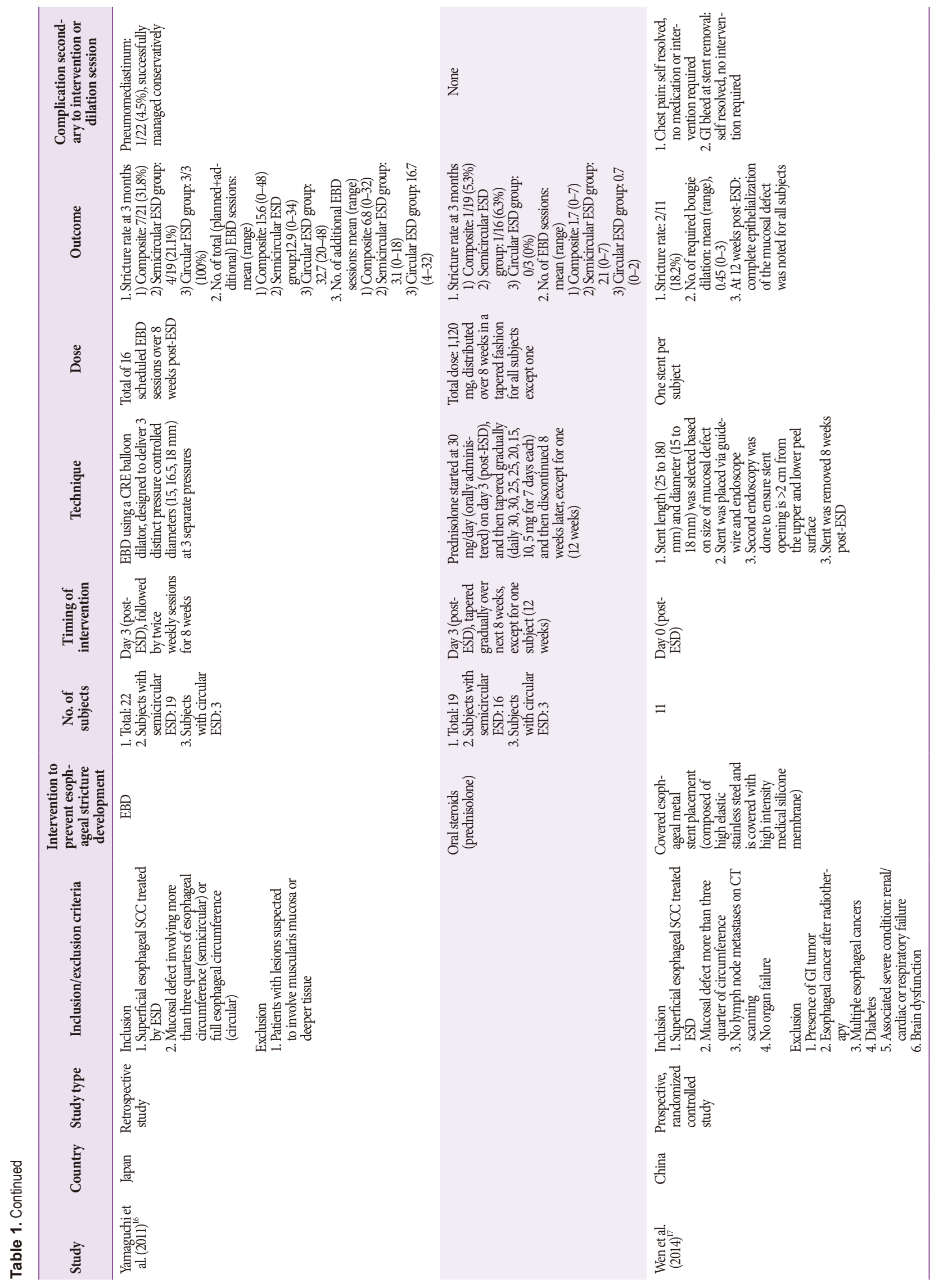




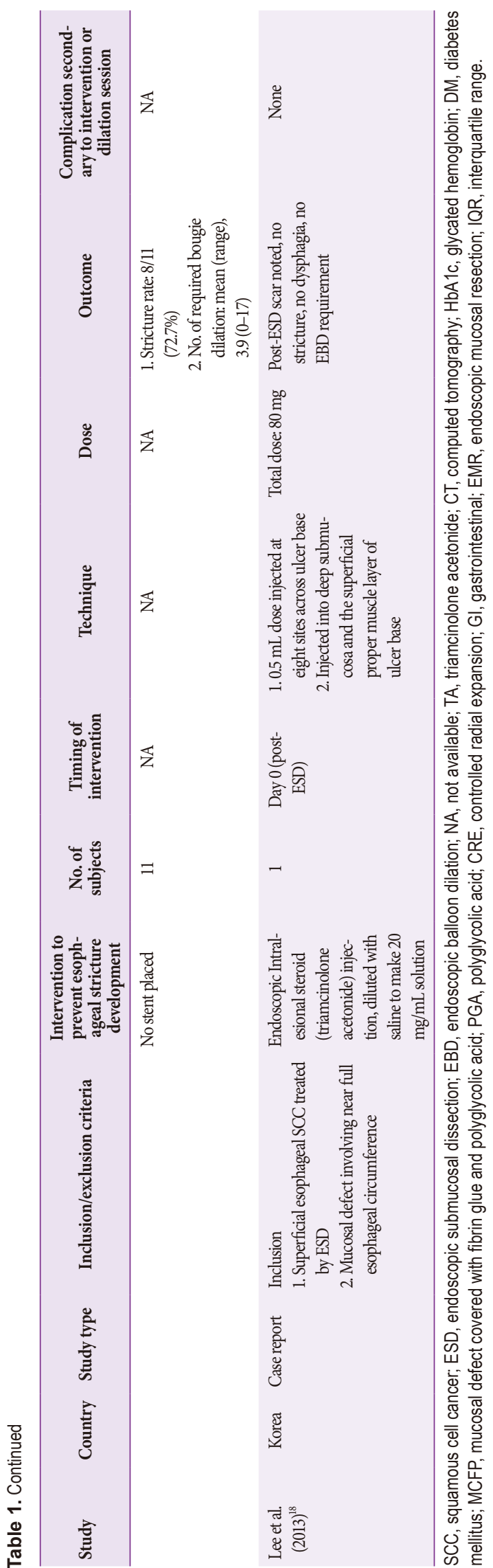

ES. ${ }^{6}$ There has been a constant effort to minimize the rate of ES after ESD. In this review article, we have summarized case reports, prospective single-center studies, and randomized controlled trials describing the various methods intended to reduce the rate of post-ESD ES. Indications, techniques, outcomes, limitations, and reported complications are discussed.

\section{MATERIALS AND METHODS}

An extensive English language literature search was conducted through May 2015, using Pubmed, Medline, and Google to identify peer-reviewed original and review articles using the following key words: 'esophageal cancer', 'endoscopic submucosal dissection', and 'esophageal stricture prophylaxis'. Only studies on humans were selected. The references of the pertinent studies were manually searched to identify additional relevant studies. The indications, procedural details, technical success rates, clinical outcomes, complications, and limitations were considered as part of the inclusion criteria. The searches yielded case reports, prospective single center studies, and a few randomized controlled trials.

\section{RESULTS}

Twelve original articles were considered appropriate to be included in the review article. Ten studies were from Japan, which included two prospective studies that used a historical population as the control group, ${ }^{7,8}$ seven single-center prospective studies, ${ }^{9-15}$ and one retrospective study. ${ }^{16}$ One prospective randomized controlled study from China ${ }^{17}$ and one case report from Korea ${ }^{18}$ were also included in the review. All included studies have been summarized in Table 1.

\section{DISCUSSION}

\section{Indications}

Patients with superficial or early EC, who were considered appropriate for ESD, were included by the authors of all the studies. All selected patients had an expected post-ESD mucosal defect of more than half of the esophageal circumference. ${ }^{7-18}$ There is a strong correlation between the extent of mucosal defect and the incidence of ES after ESD. There was a wide variation in the extent of mucosal defect among the subjects from each study. The procedure details for the ESD and the resultant size of mucosal defect for subjects across all studies have been summarized in Table 2 .

Subjects with evidence of lymph node metastases, active 
Table 2. Procedure Details of Endoscopic Submucosal Dissection and Resultant Mucosal Defect Size across Subjects for Each Study

\begin{tabular}{|c|c|c|c|c|c|}
\hline Study & Country & Study type & $\begin{array}{c}\text { Intervention to prevent } \\
\text { esophageal stricture } \\
\text { development }\end{array}$ & ESD & $\begin{array}{c}\text { Size of mucosal } \\
\text { defect }\end{array}$ \\
\hline \multirow[t]{2}{*}{$\begin{array}{l}\text { Hashimoto et al. } \\
\qquad(2011)^{7}\end{array}$} & Japan & Prospective study & ETI, $10 \mathrm{mg} / \mathrm{mL}$ solution & $\begin{array}{l}\text { 1. Resection size }(\mathrm{mm}) \text { : mean } \\
\text { (range), } 54.9(28-67) \\
\text { 2. ESD procedure time }(\mathrm{min}) \text { : mean } \\
\text { (range), } 150.5(90-290)\end{array}$ & $\begin{array}{l}\text { More than three quarter } \\
\text { but less than whole } \\
\text { circumference }\end{array}$ \\
\hline & & & $\begin{array}{l}\text { Historical control group } \\
\text { (no intervention) }\end{array}$ & $\begin{array}{l}\text { 1. Resection size }(\mathrm{mm}) \text { : mean } \\
\text { (range), } 62.4(40-100) \\
\text { 2. ESD procedure time }(\mathrm{min}) \text { : mean } \\
\text { (range), } 186.2(78-240)\end{array}$ & \\
\hline \multirow[t]{2}{*}{$\begin{array}{l}\text { Hanaoka et al. } \\
\qquad(2012)^{8}\end{array}$} & Japan & Prospective study & $\begin{array}{l}\text { Endoscopic intralesional } \\
\text { steroid (triamcinolone } \\
\text { acetonide) injection, } \\
\text { diluted with saline to } \\
\text { make } 5 \mathrm{mg} / \mathrm{mL} \text { solu- } \\
\text { tion }\end{array}$ & $\begin{array}{l}\text { 1. Mucosal incision and submucosal } \\
\text { dissection were performed with } \\
\text { a flush knife/hook knife/muco- } \\
\text { sectomy and } 0.4 \% \text { hyaluronic } \\
\text { acid solution used for submucosa } \\
\text { injection } \\
\text { 2. Minor bleeding was stopped us- } \\
\text { ing endoscopy knives in a forced } \\
\text { coagulation mode } \\
\text { 3. Major bleeding was coagulated } \\
\text { with hemostatic forceps, using the } \\
\text { soft coagulation mode at } 80 \mathrm{~W}\end{array}$ & $\begin{array}{l}\text { Length of mucosal defect } \\
(\mathrm{mm}): \text { mean } \pm \text { SD, } 58 \pm 11\end{array}$ \\
\hline & & & $\begin{array}{l}\text { Historical control group } \\
\text { (no intervention) }\end{array}$ & NA & $\begin{array}{l}\text { Length of mucosal defect } \\
\text { (mm): mean } \pm \text { SD } \\
52 \pm 18\end{array}$ \\
\hline \multirow[t]{2}{*}{ Mori et al. (2013) ${ }^{9}$} & Japan & $\begin{array}{l}\text { Prospective, ran- } \\
\text { domized study }\end{array}$ & $\begin{array}{l}\text { Local steroid injection } \\
\text { and balloon dilation }\end{array}$ & $\begin{array}{l}\text { 1. Resection size }(\mathrm{mm}) \text { : mean } \\
\text { (range), } 54.2(28-80) \\
\text { 2. ESD procedure time (min): } \\
\text { mean (range), } 195.7(65-300)\end{array}$ & $\begin{array}{l}\text { Circumference ratio of } \\
\text { lesion (\%): mean } \pm \text { SD, } \\
84 \pm 15\end{array}$ \\
\hline & & & $\begin{array}{l}\text { Steroid gel application } \\
\text { and balloon dilation }\end{array}$ & $\begin{array}{l}\text { 1. Resection size }(\mathrm{mm}) \text { : mean } \\
\text { (range), } 57.1(40-80) \\
\text { 2. ESD procedure time (min): } \\
\text { mean (range), } 179.2(90-300)\end{array}$ & $\begin{array}{l}\text { Circumference ratio of } \\
\text { lesion (\%): mean } \pm \text { SD } \\
82 \pm 14\end{array}$ \\
\hline \multirow[t]{2}{*}{$\begin{array}{l}\text { Takahashi et al. } \\
\qquad(2015)^{10}\end{array}$} & Japan & $\begin{array}{l}\text { Prospective } \\
\text { randomized } \\
\text { controlled, open } \\
\text { label, single } \\
\text { center study }\end{array}$ & $\begin{array}{l}\text { Endoscopic steroid } \\
\text { injection therapy }\end{array}$ & $\begin{array}{l}\text { 1. Size of resected specimen }(\mathrm{mm}) \text { : } \\
\text { mean } \pm S D(\text { range }), 68 \pm 14(43-97) \\
\text { 2. Operation time }(\mathrm{min}): \text { mean } \pm S D \\
\text { (range), } 89.6 \pm 37.5(36-176)\end{array}$ & $\begin{array}{l}\text { Circumferential extent } \\
1 . \geq 2 / 3 \text { to }<3 / 4: 4 \text { subjects } \\
\text { 2. } \geq 3 / 4 \text { to }<1: 7 \text { subjects } \\
\text { 3. }=1: 5 \text { subjects }\end{array}$ \\
\hline & & & None & $\begin{array}{l}\text { 1. Size of resected specimen }(\mathrm{mm}): \\
\text { mean } \pm \text { SD (range), } 62 \pm 17(39-101) \\
\text { 2. Operation time (min): mean } \pm \text { SD } \\
\text { (range), } 88.3 \pm 44.5(44-235)\end{array}$ & $\begin{array}{l}\text { Circumferential extent } \\
1 . \geq 2 / 3 \text { to }<3 / 4: 6 \text { subjects } \\
\text { 2. } \geq 3 / 4 \text { to }<1: 5 \text { subjects } \\
\text { 3. }=1: 5 \text { subjects }\end{array}$ \\
\hline $\begin{array}{l}\text { Ohki et al. } \\
(2012)^{11}\end{array}$ & Japan & $\begin{array}{l}\text { Prospective open } \\
\text { label, single arm, } \\
\text { single center } \\
\text { study }\end{array}$ & $\begin{array}{l}\text { Transplantation of } \\
\text { autologous cell sheets } \\
\text { to ulcer surfaces via an } \\
\text { endoscope }\end{array}$ & $\begin{array}{l}\text { 1. ESD using a hook knife } \\
\text { 2. Iodine staining to identify the site } \\
\text { 3. Glycerol and carmine solution } \\
\text { was injected to separate the } \\
\text { mucosal layer }\end{array}$ & $\begin{array}{l}\text { Circumference } \\
\text { 1. Half: } 1 \text { subject } \\
\text { 2. Two third: } 4 \text { subjects } \\
\text { 3. Three fourth: } 3 \text { subjects } \\
\text { 4. Almost whole: } 1 \\
\text { subject }\end{array}$ \\
\hline $\begin{array}{l}\text { Iizuka et al. } \\
\qquad(2015)^{12}\end{array}$ & Japan & $\begin{array}{l}\text { Prospective, single } \\
\text { center study }\end{array}$ & MCFP technique & $\begin{array}{l}\text { 1. An EG450-RD5 endoscope and a } \\
\text { dual knife for ESD } \\
\text { 2. Glycerol with small amounts of } \\
\text { indigo carmine and epinephrine } \\
\text { for injection } \\
\text { 3. ICC200 high frequency generator } \\
\text { for radiofrequency ablation }\end{array}$ & $\begin{array}{l}\text { The whole esophageal } \\
\text { circumference was } \\
\text { divided into } 12 \text { equal } \\
\text { subparts to measure the } \\
\text { size of defect } \\
\text { 1. } 7 / 12: 4 \text { subjects } \\
\text { 2. } 8 / 12: 5 \text { subjects } \\
\text { 3. } 9 / 12: 4 \text { subjects } \\
\text { 4. } 10 / 12: 1 \text { subjects } \\
\text { 5. } 11 / 12: 1 \text { subjects }\end{array}$ \\
\hline
\end{tabular}


Table 2. Continued

\begin{tabular}{|c|c|c|c|c|c|}
\hline Study & Country & Study type & $\begin{array}{c}\text { Intervention to prevent } \\
\text { esophageal stricture } \\
\text { development }\end{array}$ & ESD & $\begin{array}{l}\text { Size of mucosal } \\
\text { defect }\end{array}$ \\
\hline $\begin{array}{l}\text { Sakaguchi et al. } \\
\qquad(2015)^{13}\end{array}$ & Japan & $\begin{array}{l}\text { Prospective pilot } \\
\text { study, single } \\
\text { arm, single } \\
\text { center }\end{array}$ & $\begin{array}{l}\text { PGA sheet deployment } \\
\text { with fibrin glue }\end{array}$ & $\begin{array}{l}\text { 1. ESD using dual knife } \\
\text { 2. Chromoendoscopy using iodine } \\
\text { staining to identify the site } \\
\text { 3. Hyaluronic acid solution was } \\
\text { injected submucosally } \\
\text { 4. Size of resected specimen }(\mathrm{mm}) \text { : } \\
\text { mean } \pm \mathrm{SD}, 53.8 \pm 8.8 \\
\text { 5. Total dissection time (min): } \\
\text { mean } \pm \mathrm{SD}, 120 \pm 28.8\end{array}$ & $\begin{array}{l}\text { More than three quarter } \\
\text { of esophageal circum- } \\
\text { ference }\end{array}$ \\
\hline \multirow[t]{2}{*}{$\begin{array}{l}\text { Isomoto et al. } \\
(2011)^{14}\end{array}$} & Japan & Prospective study & EBD & $\begin{array}{l}\text { 1. Resection size (mm): mean } \\
\text { (range), } 69 \text { (43-94) } \\
\text { 2. Mucosal incision with flush knife } \\
\text { under the Endo cut } 1 \text { mode, } \\
\text { submucosal dissection with flush } \\
\text { knife under the forced coagula- } \\
\text { tion mode. Hemostatic forceps } \\
\text { un soft coagulation mode used to } \\
\text { stop achieve hemostasis. }\end{array}$ & $\begin{array}{l}\text { Full esophageal circum- } \\
\text { ference }\end{array}$ \\
\hline & & & $\begin{array}{l}\text { Oral steroids (predniso- } \\
\text { lone) }\end{array}$ & $\begin{array}{l}\text { 1. Resection size (mm): mean } \\
\text { (range), } 76.5(70-81) \\
\text { 2. Mucosal incision with flush knife } \\
\text { under the Endo cut } 1 \text { mode, } \\
\text { submucosal dissection with flush } \\
\text { knife under the forced coagula- } \\
\text { tion mode. Hemostatic forceps in } \\
\text { soft coagulation mode was used } \\
\text { to achieve hemostasis. }\end{array}$ & \\
\hline \multirow[t]{2}{*}{ Uno et al. $(2012)^{15}$} & Japan & Prospective study & EBD & $\begin{array}{l}\text { Procedure time ( } \mathrm{min}) \text { : mean } \pm S D \text {, } \\
131.6 \pm 44.4\end{array}$ & $\begin{array}{l}\text { Circumferential extent } \\
\text { 1. } \geq 3 / 4: 14 \text { subjects } \\
\text { 2. }=1: 2 \text { subjects }\end{array}$ \\
\hline & & & EBD+Tranilast & $\begin{array}{l}\text { Procedure time ( } \mathrm{min}) \text { : mean } \pm S D \text {, } \\
122.5 \pm 37.7\end{array}$ & $\begin{array}{l}\text { Circumferential extent } \\
\text { 1. } \geq 3 / 4: 12 \text { subjects } \\
\text { 2. }=1: 3 \text { subjects }\end{array}$ \\
\hline \multirow[t]{2}{*}{$\begin{array}{l}\text { Yamaguchi et al. } \\
(2011)^{16}\end{array}$} & Japan & $\begin{array}{l}\text { Retrospective } \\
\text { study }\end{array}$ & EBD & $\begin{array}{l}\text { 1. Tumor size (mm): mean (range), } \\
30.4 \text { (9-67) } \\
\text { 2. Operation time (min): mean } \\
\text { (range), } 95.5(47-168)\end{array}$ & $\begin{array}{l}\text { Circumferential extent } \\
\text { 1. } \geq 3 / 4: 19 \text { subjects } \\
\text { 2. }=1: 3 \text { subjects }\end{array}$ \\
\hline & & & $\begin{array}{l}\text { Oral steroids (predniso- } \\
\text { lone) }\end{array}$ & $\begin{array}{l}\text { 1. Tumor size }(\mathrm{mm}) \text { : mean (range), } \\
33.4(11-84) \\
\text { 2. Operation time (min): mean } \\
\text { (range), } 93.9(40-260)\end{array}$ & $\begin{array}{l}\text { Circumferential extent } \\
\text { 1. } \geq 3 / 4: 16 \text { subjects } \\
\text { 2. }=1: 3 \text { subjects }\end{array}$ \\
\hline \multirow[t]{2}{*}{$\begin{array}{l}\text { Wen et al. } \\
(2014)^{17}\end{array}$} & China & $\begin{array}{l}\text { Prospective, } \\
\text { randomized } \\
\text { controlled study }\end{array}$ & $\begin{array}{l}\text { Covered esophageal } \\
\text { metal stent placement } \\
\text { (composed of high } \\
\text { elastic stainless steel } \\
\text { and is covered with } \\
\text { high intensity medical } \\
\text { silicone membrane) }\end{array}$ & $\begin{array}{l}\text { ESD procedure time (min): mean } \\
\quad \text { (range), } 310.2 \pm 106.7\end{array}$ & $\begin{array}{l}\text { Circumferential extent } \\
\text { 1. } \geq 3 / 4: 5 \text { subjects } \\
\text { 2. } \geq 4 / 5: 2 \text { subjects } \\
\text { 3. }=1: 4 \text { subjects }\end{array}$ \\
\hline & & & No stent placed & $\begin{array}{l}\text { ESD procedure time (min): mean } \\
\quad(\text { range), } 265.1 \pm 106.0\end{array}$ & $\begin{array}{l}\text { Circumferential extent } \\
\text { 1. } \geq 3 / 4: 6 \text { subjects } \\
\text { 2. } \geq 4 / 5: 3 \text { subjects } \\
\text { 3. }=1: 2 \text { subjects }\end{array}$ \\
\hline
\end{tabular}


Table 2. Continued

\begin{tabular}{|c|c|c|c|c|c|}
\hline Study & Country & Study type & $\begin{array}{c}\text { Intervention to prevent } \\
\text { esophageal stricture } \\
\text { development }\end{array}$ & ESD & $\begin{array}{c}\text { Size of mucosal } \\
\text { defect }\end{array}$ \\
\hline Lee et al. $(2013)^{18}$ & Korea & Case report & $\begin{array}{l}\text { Endoscopic Intralesional } \\
\text { steroid (triamcinolone } \\
\text { acetonide) injection, } \\
\text { diluted with saline } \\
\text { to make } 20 \mathrm{mg} / \mathrm{mL} \\
\text { solution }\end{array}$ & $\begin{array}{l}\text { 1. Mucosal incision and dissection } \\
\text { were performed with a hook } \\
\text { knife and an IT knife } \\
\text { 2. } 80 \mathrm{~mL} \text { of normal saline mixed } \\
\text { with epinephrine was injected } \\
\text { to lift the mucosa including the } \\
\text { tumor } \\
\text { 3. Bleeding controlled with hemo- } \\
\text { static forceps } \\
\text { 4. Total time: } 55 \text { minutes }\end{array}$ & $\begin{array}{l}\text { Near full esophageal } \\
\text { circumference }\end{array}$ \\
\hline
\end{tabular}

ESD, endoscopic submucosal dissection; ETI, endoscopic triamcinolone injection; MCFP, mucosal defect covered with fibrin glue and polyglycolic acid; PGA, polyglycolic acid; EBD, endoscopic balloon dilation; NA, not available.

synchronous cancer, multiple ECs, prior radiation therapy/ adjuvant chemotherapy, or surgery for EC; coexisting severe comorbidities such as uncontrolled diabetes mellitus, or liver cirrhosis; or active corticosteroid or anticoagulant use were excluded from the study groups by the respective authors. ${ }^{7-18}$

\section{Type of intervention with technical aspects}

The authors have reported a wide variety of modalities used to prevent ES formation after ESD: local steroid injections, ${ }^{7-10,18}$ topical steroid gel application, ${ }^{9}$ oral steroids, ${ }^{14,16}$ pre-emptive scheduled endoscopic balloon dilation (EBD), ${ }^{14-16}$ a combination of EBD and tranilast, ${ }^{15}$ transplantation of autologous cell sheets, ${ }^{11}$ polyglycolic acid (PGA) sheets, ${ }^{12,13}$ and stents. ${ }^{14}$

\section{Steroids oral, injection, or gel application}

In a prospective study, Hashimoto et al. ${ }^{7}$ described the prophylactic use of triamcinolone acetonide (TA) injections $(10 \mathrm{mg} / \mathrm{mL})$ in an effort to prevent post-ESD ES. The author used a $25 \mathrm{G}$ needle to inject steroids in aliquots of $0.2 \mathrm{~mL}, 1$ $\mathrm{cm}$ apart in a semicircular fashion into the area of the mucosal defect. Similarly, Hanaoka et al. ${ }^{8}$ used a $25 \mathrm{G}$ needle to inject a lower concentration of TA $(5 \mathrm{mg} / \mathrm{mL})$ into the ulcer bed submucosa in 0.5 to $1.0 \mathrm{~mL}$ increments. This author used a different pattern, starting from the ulcer margin and then administering linear injections from the distal to the proximal side of the ulcer margin. Special precautions were taken to avoid intramuscular steroid injection. In a randomized trial, Mori et al. ${ }^{9}$ compared steroid injection therapy to steroid gel application. In the steroid injection arm, the author administered $0.2 \mathrm{~mL}$ TA injections $(10 \mathrm{mg} / \mathrm{mL})$ into the ulcer floor at $8 \mathrm{~mm}$ intervals, followed by a 5 minutes session of EBD. In the other arm of the study, TA gel $(10 \mathrm{~mL}$ mixed with $7.5 \mathrm{~mL}$ of endolubri jelly) was applied from the distal to the proximal end of the ulcer with a spraying tube via endoscope, which was followed by a 5 minutes session of EBD. In another study by Takahashi et al., ${ }^{10} 0.5 \mathrm{~mL}$ aliquots of TA $(10 \mathrm{mg} / \mathrm{mL})$ were injected into the ulcer base using a $25 \mathrm{G}$ needle. TA was administered, starting from the distal edge and repeating evenly at points $10 \mathrm{~mm}$ apart until the proximal edge was reached. In the case report by Lee et al., ${ }^{18}$ which involved a near-circumferential mucosal defect, the author administered a higher concentration of TA $(20 \mathrm{mg} / \mathrm{mL})$ in aliquots of $0.5 \mathrm{~mL}$, which were distributed evenly across the ulcer at eight sites.

Overall, all authors used TA as the preferred steroid agent both for the injection and gel application. Authors did use different concentrations of TA and had their own specific pattern of administering it into the ulcer base, essentially with the aim of achieving a uniform distribution across the mucosal defect. Some authors reported variations in the total steroid dose administered based on the ulcer bed size, ${ }^{7,9}$ whereas others reported using a fixed amount irrespective of the size. ${ }^{8}$ Most authors also made an extra effort to avoid injury to the muscular layer at the time of administration, as that might hamper the healing process.

In two studies, oral steroids were compared to scheduled pre-emptive EBD intended to prevent ES post ESD. ${ }^{14,16}$ In both studies, prednisolone was the drug of choice and was given to subjects on day 3 post-ESD. The regimen started with a dose of $30 \mathrm{mg}$ daily and was tapered gradually every week for a total duration of 8 weeks. The subjects ended up getting approximately 1,000 $\mathrm{mg}$ of prednisolone over the 8 -week period. Oral steroids have a potential role in ES prevention post ESD.

More information is needed to choose among the types, doses, routes, and duration of steroid administration as the preferred modality for ES prophylaxis.

\section{Endoscopic balloon dilation}

Endoscopic dilation with either a bougie or a dilator is the 
preferred treatment for ES. Few authors have extrapolated this concept to use scheduled EBD to prevent post-ESD ES..$^{14-16}$ In the three studies that tried this, EBD was performed using a controlled radial expansion balloon dilator, twice a week, for $4^{15}$ to 8 weeks, ${ }^{14,16}$ starting within a few days of ESD. Uno et al. ${ }^{15}$ described using two to three progressively larger diameter dilators per session, with the aim of not going beyond a $3 \mathrm{~mm}$ dilation each time. Yamaguchi et al. ${ }^{16}$ used a dilator, designed to deliver three different pressure-controlled diameters at three distinct points. Clinical clues such as mucosal tears or bleeding were also used to individualize the EBD treatment for each subject. All three studies compared the efficacy of a second agent to the group receiving EBD alone.

\section{Transplantation of autologous cell sheets}

Ohki et al. ${ }^{11}$ reported their unique experience of using patients' own cells to heal the mucosal defect post-ESD; thus, preventing ES. The author cultured epithelial cells from the patient's own buccal mucosa. These autologous oral mucosal epithelial sheets grown on a support membrane were transferred to the esophageal mucosal defect using endoscopic forceps. Each sheet was $23.4 \mathrm{~mm}$ in diameter and the number of sheets used to cover the ulcer base varied from two to eight depending on the size of the mucosal defect.

\section{Polyglycolic acid sheets}

PGA is an absorbable suture stiffener. It has the potential to prevent scarring and contraction after surgical interventions. Covering a mucosal defect with fibrin glue and a PGA sheet is known as the mucosal defect covered with fibrin glue and PGA sheet (MCFP) technique, and it has been applied in many fields of surgery and appears to be safe. ${ }^{19-21}$ lizuka et al. ${ }^{12}$ described their experience with PGA sheets in preventing ES after ESD. Essentially, the technique involves covering the ulcer base with PGA sheets with the assistance of a fibrinogen and thrombin spray solution. ${ }^{12}$ Sakaguchi et al. ${ }^{13}$ also used PGA sheets and fibrin glue in an effort to prevent post-ESD ES. This author used a modified version of the clip and pull method to deploy the PGA sheets. The size and number of PGA sheets used to cover the mucosal defect varied between the two studies.

\section{Tranilast}

Tranilast (N-[3,4-dimethoxycinnamoyl]-anthranilic acid) is an antiallergic reaction drug with antitumor activity and a newly evolving role in managing fibrotic pathologies. ${ }^{22}$ Uno et al. ${ }^{15}$ did a pilot study to determine the efficacy of tranilast in preventing post-ESD ES. Because of a lack of data on the effective dose and route of administration, the author used a empiric oral daily dose of $300 \mathrm{mg}$, divided in three doses to be taken with meals in addition to an EBD session.

\section{Stents}

Wen et al. ${ }^{17}$ reported the first randomized trial comparing the efficacy of esophageal stents in preventing post-ESD ES. The author used a metal stent composed of highly elastic stainless steel covered with a high-density medical silicone membrane. The stent was placed via a guide wire and endoscope and was removed after 8 weeks. The length ( 25 to 180 $\mathrm{mm}$ ) and diameter (15 to $18 \mathrm{~mm}$ ) of the stent was selected based on the size of the mucosal defect. The technical details of all the above-described procedures have been summarized in Table 1.

\section{Timing and frequency of intervention}

There is no consensus on the timing or the duration of the prophylactic intervention. Speaking physiologically, the earlier the intervention, the more efficacious it should be in preventing ES by molding the healing esophageal ulcer at the appropriate time. The duration of intervention, on the other hand, should be guided by the time required for re-epithelialization of the ulcer bed.

The majority of the authors performed their intervention to prevent ES on the day of ESD., ${ }^{8,1-13,17,18}$ Hashimoto et al. ${ }^{7}$ administered the TA injection on post-ESD days 3, 7, and 10. In his randomized study, Mori et al. ${ }^{9}$ compared TA injections to gel applications with interventions on day $5,8,12$, and 15 postESD. Scheduled pre-emptive EBD sessions were planned to start on post-ESD day 3, and were continued twice a week for the next 8 weeks. ${ }^{14,16}$ Oral steroids were also started on postESD day 3 and were continued for the next 8 weeks using a tapering regimen. ${ }^{14,16}$ Tranilast was started within the first few days of ESD and was continued on a daily basis for the next 8 weeks. ${ }^{15}$ More studies are required to form a consensus and help guide future interventions.

\section{Monitoring and follow-up}

All patients were followed clinically postintervention to detect and evaluate any symptoms of dysphagia. All subjects were scheduled to undergo either an upper endoscopy for direct visualization of the esophageal mucosa or indirect tests such as a barium contrast esophagogram to evaluate the contour and anatomy of the esophagus. The timing of the follow-up or the diagnostic test was pre-decided as per the individual study design unless a patient started to show any clinical signs of dysphagia, which resulted in an earlier diagnostic intervention. In addition, different authors used different parameters to define an ES for their respective studies.

Table 3 provides a summary of follow-up intervals, diagnostic tests, and parameters used for defining ES for each study. 
Table 3. Follow-up Intervals, Diagnostic Tests, and Stricture Definition Used across Different Studies

\begin{tabular}{|c|c|c|c|c|c|}
\hline Study & Country & Study type & $\begin{array}{l}\text { Intervention to prevent } \\
\text { esophageal stricture } \\
\text { development }\end{array}$ & Monitoring and $\mathrm{F} / \mathrm{U}$ & Stricture criteria \\
\hline \multirow[t]{2}{*}{$\begin{array}{l}\text { Hashimoto et al. } \\
\qquad(2011)^{7}\end{array}$} & Japan & Prospective study & ETI, $10 \mathrm{mg} / \mathrm{mL}$ solution & $\begin{array}{l}\text { Esophagoscopy routinely at } 1 \\
\text { week, } 1,6 \text { months, and } 1 \text { year } \\
\text { post-ETI, clinical F/U for } \\
\text { dysphagia }\end{array}$ & $\begin{array}{l}\text { Standard endoscope } \\
\text { GIF-Q240 cannot pass } \\
\text { through the ESD scar }\end{array}$ \\
\hline & & & $\begin{array}{l}\text { Historical control group } \\
\text { (no intervention) }\end{array}$ & NA & \\
\hline $\begin{array}{l}\text { Hanaoka et al. } \\
(2012)^{8}\end{array}$ & Japan & Prospective study & $\begin{array}{l}\text { Endoscopic Intralesional } \\
\text { steroid (triamcinolone } \\
\text { acetonide) injection, } \\
\text { diluted with saline } \\
\text { to make } 5 \mathrm{mg} / \mathrm{mL} \\
\text { solution }\end{array}$ & $\begin{array}{l}\text { Endoscopy (EGD) routinely at } \\
2 \text { months post-ESD or earlier } \\
\text { if dysphagia was reported }\end{array}$ & $\begin{array}{l}\text { Dysphagia to solids } \\
\text { (dysphagia score } 2 \text { ) } \\
\text { or an inability to pass } \\
\text { a } \geq 9.2 \mathrm{~mm} \text { diameter } \\
\text { endoscope }\end{array}$ \\
\hline
\end{tabular}

\begin{tabular}{|c|c|c|c|c|}
\hline & & & $\begin{array}{l}\text { Historical control group } \\
\text { (no intervention) }\end{array}$ & NA \\
\hline Mori et al. $(2013)^{9}$ & Japan & $\begin{array}{l}\text { Prospective, ran- } \\
\text { domized study }\end{array}$ & $\begin{array}{l}\text { Local steroid injection } \\
\text { and balloon dilation }\end{array}$ & $\begin{array}{l}\text { Gastrograffin esophagograms } \\
\text { on day } 5,8,12,15,20,30,60 \\
\text { and clinical F/U for dysphagia }\end{array}$ \\
\hline
\end{tabular}

nability to pass a $10 \mathrm{~mm}$ diameter endoscope through ESD scar in a patient complaining of dysphagia and requiring EBD

Takahashi et al. Japan $\begin{gathered}\text { Prospective ran- } \\ \text { domized con- } \\ \text { trolled, open label, } \\ \text { single center study }\end{gathered}$

Ohki et al.

$(2012)^{11}$

\begin{tabular}{|c|c|c|c|}
\hline $\begin{array}{l}\text { Iizuka et al. } \\
(2015)^{12}\end{array}$ & Japan & $\begin{array}{l}\text { Prospective, single } \\
\text { center study }\end{array}$ & MCFP technique \\
\hline $\begin{array}{l}\text { Sakaguchi et al. } \\
(2015)^{13}\end{array}$ & Japan & $\begin{array}{l}\text { Prospective pilot } \\
\text { study, single arm, } \\
\text { single center }\end{array}$ & $\begin{array}{l}\text { PGA sheet deployment } \\
\text { with fibrin glue }\end{array}$ \\
\hline
\end{tabular}

\begin{tabular}{|c|c|}
\hline $\begin{array}{l}\text { Isomoto et al. } \\
(2011)^{14}\end{array}$ & Japan \\
\hline
\end{tabular}

Transplantation of autologous cell sheets endoscope label, single arm, single center study

\section{MCFP technique}

None

Steroid gel application and balloon dilation

Endoscopic steroid injection therapy to ulcer surfaces via an

EGD at 1,2,4, and 6 weeks after ESD F/U (day): median (range), 352 (60-535)

1. EGD, 6 days post-injection therapy

2. Barium contrast esophagography in patients complaining of dysphagia or 4 weeks after the last EGD if patients were asymptomatic

Barium contrast esophagography in patients complaining of dysphagia or 4 weeks after the last EGD if patients were asymptomatic

Weekly endoscopy until epithelialization was complete

Scheduled endoscopy on day 7 and 28 or if clinically indicated based on symptom

1. F/U endoscopy with iodine staining and biopsy if abnormal mucosa noted at 3,6 , and 12 months post-ESD

2. CT scan of cervix, thorax and abdomen at 3, 6 and 12 months post-ESD

3. Clinical F/U for dysphagia

\section{Esophageal diameter $<11 \mathrm{~mm}$ or inability to achieve or maintain a diameter of $14 \mathrm{~mm}$ despite dilatation every 2-4 weeks}

\section{Inability to pass $\mathrm{H} 260$} endoscope through the ESD scar

\section{Inability to pass $9.8 \mathrm{~mm}$ diameter endoscope (GIF Q240 or GIF H260) through the ESD scar}

NA 
Table 3. Continued

\begin{tabular}{|c|c|c|c|c|c|}
\hline Study & Country & Study type & $\begin{array}{l}\text { Intervention to prevent } \\
\text { esophageal stricture } \\
\text { development }\end{array}$ & Monitoring and $\mathrm{F} / \mathrm{U}$ & Stricture criteria \\
\hline & & & $\begin{array}{l}\text { Oral steroids (predniso- } \\
\text { lone) }\end{array}$ & & \\
\hline \multirow[t]{2}{*}{ Uno et al. $(2012)^{15}$} & Japan & Prospective study & EBD & $\begin{array}{l}\text { 1. Scheduled consultations and } \\
\text { F/U examinations by EGD } \\
\text { (earlier if clinically warrant- } \\
\text { ed) for } 48 \text { weeks } \\
\text { 3. F/U period: mean } \pm S D \text {, } \\
28.4 \pm 11.9 \text { months }\end{array}$ & $\begin{array}{l}\text { Inability to pass } 10.8 \mathrm{~mm} \\
\text { standard endoscope } \\
\text { through the suspected } \\
\text { esophageal region }\end{array}$ \\
\hline & & & EBD+Tranilast & $\begin{array}{l}\text { 1. Scheduled consultations and } \\
\text { F/U examinations by EGD } \\
\text { (earlier if clinically warrant- } \\
\text { ed) for } 48 \text { weeks } \\
\text { 2. For tranilast- physical ex- } \\
\text { amination and blood work } \\
\text { up including complete blood } \\
\text { count, hepatic and kidney } \\
\text { function tests weekly for first } \\
4 \text { weeks, and thereafter at } 8 \text {, } \\
\text { 16, 24, and } 48 \text { weeks post- } \\
\text { ESD } \\
\text { 3. F/U period: mean } \pm S D \text {, } \\
\text { 24.3 } \pm 7.4 \text { months }\end{array}$ & \\
\hline \multirow[t]{2}{*}{$\begin{array}{l}\text { Yamaguchi et al. } \\
(2011)^{16}\end{array}$} & Japan & Retrospective study & EBD & $\begin{array}{l}\text { 1. F/U endoscopy with iodine } \\
\text { staining and biopsy if abnor- } \\
\text { mal mucosa noted at } 1,3,6 \text {, } \\
\text { and } 12 \text { months post-ESD } \\
\text { 2. CT scan of neck, chest and } \\
\text { abdomen annually, post-ESD } \\
\text { 3. Clinical F/U for dysphagia }\end{array}$ & NA \\
\hline & & & $\begin{array}{l}\text { Oral steroids (predniso- } \\
\text { lone) }\end{array}$ & & \\
\hline \multirow[t]{2}{*}{$\begin{array}{l}\text { Wen et al. } \\
(2014)^{17}\end{array}$} & China & $\begin{array}{l}\text { Prospective, ran- } \\
\text { domized con- } \\
\text { trolled study }\end{array}$ & $\begin{array}{l}\text { Covered esophageal } \\
\text { metal stent placement } \\
\text { (composed of high } \\
\text { elastic stainless steel } \\
\text { and is covered with } \\
\text { high intensity medical } \\
\text { silicone membrane) }\end{array}$ & $\begin{array}{l}\text { 1. Routine } \mathrm{F} / \mathrm{U} \text { gastroscopy was } \\
\text { done, } 4 \text { weeks post-ESD } \\
\text { 2. Routine } \mathrm{F} / \mathrm{U} \text { endoscopy was } \\
\text { done at } 12 \text { weeks post-ESD } \\
\text { or when patient exhibited } \\
\text { dysphagia symptoms to solid } \\
\text { food }\end{array}$ & $\begin{array}{l}<9.8 \mathrm{~mm} \text { opening that } \\
\text { did not permit the } \\
\text { passage of GIF H260 } \\
\text { endoscope through it }\end{array}$ \\
\hline & & & No stent placed & $\begin{array}{l}\text { Routine } \mathrm{F} / \mathrm{U} \text { endoscopy was } \\
\text { done at } 12 \text { weeks post-ESD } \\
\text { or when patient exhibited } \\
\text { dysphagia symptoms to solid } \\
\text { food }\end{array}$ & \\
\hline Lee et al. $(2013)^{18}$ & Korea & Case report & $\begin{array}{l}\text { Endoscopic intralesional } \\
\text { steroid (triamcinolone } \\
\text { acetonide) injection, } \\
\text { diluted with saline to } \\
\text { make } 20 \mathrm{mg} / \mathrm{mL} \text { solu- } \\
\text { tion }\end{array}$ & $\begin{array}{l}\text { Esophagography at } 2 \text { and } 4 \\
\text { weeks, EGD at } 4 \text { months post- } \\
\text { ESD, clinical F/U for dyspha- } \\
\text { gia }\end{array}$ & NA \\
\hline
\end{tabular}

ETI, endoscopic triamcinolone injection; F/U, follow-up; EGD, esophagogastroduodenoscopy; ESD, endoscopic submucosal dissection; EBD, endoscopic balloon dilation; NA, not available. MCFP, mucosal defect covered with fibrin glue and polyglycolic acid; PGA, polyglycolic acid; CT, computed tomography. 


\section{Outcome}

The ideal way to measure the efficacy of the above-mentioned interventions is to compare the incidence of ESs postESD. Another indirect measure is to compare the number of required sessions of EBD for each group of subjects.

\section{Esophageal stricture}

Hashimoto et al. ${ }^{7}$ reported an ES rate of 19\% (4/21) in the study arm receiving TA injections as compared to $75 \%$ (15/20) in the control group. A similar trend was shown by Hanaoka et al. ${ }^{8}$ for the ES rate post-TA injection therapy $(10 \%, 3 / 30)$ in the study arm versus $66 \%(19 / 29)$ in the control group. The two studies did differ in the timing and frequency of TA injection post-ESD as described above. Although both of these studies $^{7,8}$ showed a significant reduction in ES incidence postTA injection, the control groups were historical population groups and therefore the inferences from these results cannot be generalized. The randomized controlled trial by Takahashi et al. ${ }^{10}$ comparing TA injections with no therapy helps us to answer this question more accurately. The ES rate for the TA study arm was $62.5 \%$ (10/16), which is still pretty high but is lower than that of the control group $(87.5 \%, 14 / 16){ }^{10}$ Therefore, we can safely conclude that TA injection therapy does prevent some strictures post-ESD. In a case report, Lee et al. ${ }^{18}$ reported complete success in preventing ES post-ESD with prophylactic TA injection therapy. This case also had a near whole-circumferential esophageal mucosal defect, thus a higher potential for ES. The success with TA therapy in preventing ES in this case is strongly suggestive of its efficacy. The question that remains unanswered is why the results are not uniform. Possibilities include variations in technique and individual patient characteristics.

Mori et al. ${ }^{9}$ conducted a randomized head-to-head comparison between steroid injection therapy plus EBD versus steroid gel application plus EBD. No significant difference was observed in the ES rate between the two groups. The author did report that the requirement for technical expertise and the total procedure time for the gel application study arm (6.87 minutes) was lower (although not statistically significant) than that of injection group (total procedure time 7.33 minutes). In addition, gel application provides an alternative method of stricture prevention for subjects on oral anticoagulation or antiplatelet medications, as it obviates the need for needle injection; thus, lowering the bleeding risk.

Two studies illustrated the efficacy of oral steroids in preventing post-ESD ES. In a small prospective study by Isomoto et al., ${ }^{14}$ the study arm (four subjects) receiving oral prednisolone developed strictures in only $50 \%$ of the population as compared to $100 \%$ of the subjects (three) undergoing scheduled EBD post-ESD. A similar trend was shown in a larger prospective study by Yamaguchi et al. ${ }^{16}$ Out of 19 subjects who received oral prednisolone, only one developed ES (5.3\%) post-ESD, as compared to $31.8 \%$ (7 out of 21 ) in the group that received pre-emptive EBD. ${ }^{16}$ The study reported the same trend for patients with either semicircular (more than three quarters circumference) or circular (full circumference) mucosal defects post-ESD. ${ }^{16}$

An oral steroid regimen is an interesting alternative to injection/gel administration. It does not require any invasive test; thus, decreasing the treatment cost, and provides a uniform distribution of steroid over larger esophageal mucosal defects. Oral steroids also obviate the concern for procedure-related complications seen with injection treatment, but do come with the concern for possible systemic side effects. However, none of the subjects in either of the studies ${ }^{14,16}$ had any adverse effect attributable to the steroid therapy.

The study by Ohki et al. ${ }^{11}$ demonstrated that autologous cell sheet transplantation was successful in preventing ES formation in eight out of nine subjects. The only failure $(11.1 \%, 1 / 9)$ was the subject with a full circumferential mucosal defect. Although the study was small, the results are promising. There are no studies comparing autologous cell sheet transplantation with steroid therapy or EBD for preventing post-ESD ES.

Results from the study by lizuka et al. ${ }^{12}$ were suggestive of MCFP's efficacy in preventing ES post-ESD. Six weeks after ESD, only one subject out of 13 (7.7\%) developed ES. Two other subjects were reported to have dysphagia post-ESD but did not have ES on evaluation. Another study by Sakaguchi et al. ${ }^{13}$ also used PGA and fibrin glue as a means of preventing ES but the results were not consistent with that of lizuka et al. ${ }^{12}$ In their study, three out of eight subjects (37.5\%) developed ES. The mean time to stricture occurrence was $28 \pm 7$ days. More experience with PGA is necessary before reaching a conclusion about its role in post-ESD ES prevention.

In his pilot randomized study, Uno et al. ${ }^{15}$ illustrated the efficacy of tranilast in preventing ES after ESD. Both study arms underwent scheduled EBD sessions. The addition of tranilast decreased the incidence of ES by almost half $(33.8 \%$ as compared to $68.8 \%$ in the control arm). ${ }^{15}$

Wen et $\mathrm{al}^{17}$ conducted a randomized study comparing the role of metal stents in preventing ES post-ESD. The intervention arm had an ES rate of $18.2 \%$ (2/11) as compared to $72.7 \%$ $(8 / 11)$ in the control arm. The results are strongly suggestive of the efficacy of metal stents in preventing ES after ESD.

\section{Endoscopic balloon dilation}

Steroids have an anti-inflammatory effect and modulate wound healing by decreasing collagen production. ${ }^{23}$ Steroids are supposed to not only decrease the ES rate but may also modify the response to dilation therapy for strictures. The 
mean number of EBD sessions required among subjects who have received prophylactic TA injections post-ESD was 1.7 (range, 0 to 15), much lower when compared to the historical control group (mean, 6.6; range, 0 to 20) in the study by Hashimoto et al. ${ }^{7}$ A similar trend was seen in the TA injection study by Hanaoka et al. ${ }^{8}$ (number of EBD sessions ranged from 0 to 2 vs. 0 to 15 in the historical control group). In the randomized study by Takahashi et al. ${ }^{10}$ the mean number of EBD sessions $(6.1 \pm 6.2)$ and the mean duration of dilation therapy (3.5 \pm 4.0 months) for the study arm (TA injection) were much lower than that of the control arm (mean number of EBD sessions $12.5 \pm 10.0$, mean duration of dilation therapy $6.1 \pm 5.0$ months). Isomoto et al. ${ }^{14}$ and Yamaguchi et al. ${ }^{16}$ showed a statistically significant $(p<0.05$ and $p<0.0001$, respectively) decrease in the mean number of EBD sessions required with oral prednisolone as compared to the EBD control group. The trend was consistent across all subjects irrespective of the size of the mucosal defect. ${ }^{16}$ All of these results are consistent with the fact that steroids do modulate wound healing, and thus can alter the response of ES to EBD therapy.

In the head-to-head randomized trial of TA injection plus EBD vs. TA gel plus EBD treatment, the mean number of EBD sessions post day 20 was 4.27 for the injection group, which was significantly higher $(p<0.05)$ than 1.6 for the gel group. ${ }^{3}$ Clearly, the balance tilts in favor of steroid gel application despite the absence of a significant difference between the ES rate across the two study arms.

In the study by Ohki et al.," ${ }^{11}$ only one subject developed ES post-autologous cell sheet transplantation. The subject had a full circumferential mucosal defect and required 21 EBD sessions to relieve the stenosis.

In the study by Iizuka et al., ${ }^{12}$ only one patient developed ES post-MCFP and required five EBD sessions to relieve the stenosis. In another study involving the use of PGA to prevent ES postESD, the mean number of EBD sessions required was $0.8 \pm 1.2$.

Uno et al.s experience with tranilast showed promising results in a long follow-up study. The median number of additional EBD sessions required by the tranilast arm by the end of 48 weeks was zero as compared to four for the control arm $(p<0.0138){ }^{15}$

In the randomized controlled study by Wen et al. ${ }^{17}$ evaluating the efficacy of metallic esophageal stents in preventing ES after ESD, the mean number of bougie dilations required was 0.45 (range, 0 to 3 ) for the stent arm as compared to 3.9 (range, 0 to 17) for the arm without the stent.

Experience with autologous cell sheet transplants, PGA sheets, tranilast, and esophageal stents is still in its infancy and it is hard to draw any firm conclusions. The results have shown the promise of these modalities and more studies are necessary.

\section{Adverse events}

Any intervention comes with possible complications. Although most of the interventions discussed here are relatively benign, a few complications have been reported. Overall, bleeding and perforation were the two common complications reported by the authors.

\section{Bleeding and perforation}

In the study by Hanaoka et al., ${ }^{8}$ among the patients who received TA injections, two (7\%) developed complications. One patient presented with black tarry stools 8 days postESD, which was attributed to an esophageal source and required endoscopic hemostasis. Another patient developed a deep submucosal tear without perforation, noticed during a stricture evaluation 2 months post-ESD. The subject was successfully managed conservatively. In the study by Mori et al., two patients $(9.5 \%)$ in the study arm receiving TA injections reported esophageal bleeding within the first 2 weeks postESD, which required endoscopic hemostasis as compared to a $0 \%$ complication rate in the steroid gel intervention arm. Both of these subjects were on oral anticoagulation. Steroid gel application offers an alternative to injection therapy especially among patients at higher bleeding risk, such as those on oral anticoagulants and antiplatelets. Takahashi et al. ${ }^{10}$ reported esophageal perforation occurred in one subject in each of the study arms. The perforation was attributed to the EBD session and not to the TA injection therapy. The intervention arm was reported to have one perforation for $97 \mathrm{EBD}$ sessions in total, whereas the control arm had one perforation for $200 \mathrm{EBD}$ sessions. Uno et al. ${ }^{15}$ also reported one case of perforation secondary to additional EBD sessions (6.25\%), successfully managed in a conservative manner. Another way to represent these results is that one out of 98 additional EBD sessions resulted in perforation $(1.02 \%) .{ }^{15}$ In contrast to the above two studies, ${ }^{10,15}$ where the esophageal perforation was attributed to the additional therapeutic EBD sessions performed to treat already-formed ES, Yamaguchi et al. ${ }^{16}$ reported one case of pneumomediastinum secondary to the scheduled pre-emptive EBD (1 out of 22 subjects, 4.5\%). The subject improved with conservative management. In the study by Iizuka et al., ${ }^{12}$ one subject (out of 15) developed esophageal bleeding post-ESD that was managed conservatively and no blood transfusion was required.

\section{Miscellaneous}

Ohki et al. ${ }^{11}$ reported that four out of nine subjects developed a high-grade fever, but it resolved without any intervention. Wen et al. ${ }^{17}$ reported that in the intervention arm 
(esophageal metal stent), one subject developed chest pain that resolved without any intervention and another subject developed transient bleeding at the time of stent removal that also resolved, requiring no intervention.

ESD and intervention type are not the only underlying factors predisposing to complications. Patient factors and EBD sessions also play an important role. Nonetheless, the frequency of reported complications in each of the respective studies is low and most of them were managed conservatively without any intervention.

\section{CONCLUSIONS}

ES is the most common complication post-ESD and is the most common cause of morbidity among patients with EC treated via ESD. There has been a paradigm shift in the management of ES in the last few years, with the focus shifting from treatment to prophylaxis. Both local and systemic prophylactic steroid use has shown the most consistent and promising results with minimal complications for prevention of ES post-ESD. Autologous cell sheet transplants, PGA sheets, tranilast, and esophageal metal stents show promise in preventing ES formation but are still relatively new. Further experience with current treatment options, development of novel strategies, and refinement of endoscopic technique in delivering the targeted intervention will help expand the field of preventive care in the future. The preliminary reports appear promising but larger multicentric prospective studies with longer follow-up and head-to-head comparison trials with current treatment options are needed to assist in developing consensus guidelines.

\section{Conflicts of Interest}

The authors have no financial conflicts of interest.

\section{REFERENCES}

1. American Cancer Society. What are the key statistics about cancer of the esophagus? [Internet]. Atlanta: American Cancer Society; c2016 [updated $2016 \mathrm{Feb} 4$; cited $2016 \mathrm{Feb} 22$ ]. Available from: http://www.cancer. org/cancer/esophaguscancer/detailedguide/esophagus-cancer-key-statistics.

2. American Cancer Society. Survival rates for cancer of the esophagus by stage [Internet]. Atlanta: American Cancer Society; c2016 [updated 2016 Feb 4; cited 2016 Feb 22]. Available from: http://www.cancer.org/cancer/ esophaguscancer/detailedguide/esophagus-cancer-survival-rates.

3. Lightdale CJ. Endoscopic treatments for early esophageal cancer. Gastroenterol Hepatol (N Y) 2007;3:904-906.

4. Ishihara R, Iishi $\mathrm{H}$, Uedo $\mathrm{N}$, et al. Comparison of EMR and endoscopic submucosal dissection for en bloc resection of early esophageal cancers in Japan. Gastrointest Endosc 2008;68:1066-1072.

5. Sun F, Yuan P, Chen T, Hu J. Efficacy and complication of endoscopic submucosal dissection for superficial esophageal carcinoma: a systematic review and meta-analysis. J Cardiothorac Surg 2014;9:78.

6. Ono S, Fujishiro M, Niimi K, et al. Predictors of postoperative stricture after esophageal endoscopic submucosal dissection for superficial squamous cell neoplasms. Endoscopy 2009;41:661-665.

7. Hashimoto S, Kobayashi M, Takeuchi M, Sato Y, Narisawa R, Aoyagi Y. The efficacy of endoscopic triamcinolone injection for the prevention of esophageal stricture after endoscopic submucosal dissection. Gastrointest Endosc 2011;74:1389-1393.

8. Hanaoka N, Ishihara R, Takeuchi Y, et al. Intralesional steroid injection to prevent stricture after endoscopic submucosal dissection for esophageal cancer: a controlled prospective study. Endoscopy 2012;44:10071011.

9. Mori H, Rafiq $\mathrm{K}$, Kobara $\mathrm{H}$, et al. Steroid permeation into the artificial ulcer by combined steroid gel application and balloon dilatation: prevention of esophageal stricture. J Gastroenterol Hepatol 2013;28:9991003.

10. Takahashi H, Arimura Y, Okahara S, et al. A randomized controlled trial of endoscopic steroid injection for prophylaxis of esophageal stenoses after extensive endoscopic submucosal dissection. BMC Gastroenterol 2015;15:1.

11. Ohki T, Yamato M, Ota M, et al. Prevention of esophageal stricture after endoscopic submucosal dissection using tissue-engineered cell sheets. Gastroenterology 2012;143:582-588.

12. Iizuka T, Kikuchi D, Yamada A, Hoteya S, Kajiyama Y, Kaise M. Polyglycolic acid sheet application to prevent esophageal stricture after endoscopic submucosal dissection for esophageal squamous cell carcinoma. Endoscopy 2015;47:341-344.

13. Sakaguchi Y, Tsuji Y, Ono S, et al. Polyglycolic acid sheets with fibrin glue can prevent esophageal stricture after endoscopic submucosal dissection. Endoscopy 2015;47:336-340.

14. Isomoto H, Yamaguchi N, Nakayama T, et al. Management of esophageal stricture after complete circular endoscopic submucosal dissection for superficial esophageal squamous cell carcinoma. BMC Gastroenterol 2011;11:46.

15. Uno K, lijima K, Koike T, et al. A pilot study of scheduled endoscopic balloon dilation with oral agent tranilast to improve the efficacy of stricture dilation after endoscopic submucosal dissection of the esophagus. J Clin Gastroenterol 2012;46:e76-e82.

16. Yamaguchi N, Isomoto H, Nakayama T, et al. Usefulness of oral prednisolone in the treatment of esophageal stricture after endoscopic submucosal dissection for superficial esophageal squamous cell carcinoma. Gastrointest Endosc 2011;73:1115-1121.

17. Wen J, Lu Z, Yang Y, et al. Preventing stricture formation by covered esophageal stent placement after endoscopic submucosal dissection for early esophageal cancer. Dig Dis Sci 2014;59:658-663.

18. Lee WJ, Jung HY, Kim do H, et al. Intralesional steroid injection to prevent stricture after near-circumferential endosopic submucosal dissection for superficial esophageal cancer. Clin Endosc 2013;46:643-646.

19. Yonezawa H, Yanamoto S, Kawasaki G, Umeda M. Polyglycolic acid sheets with fibrin glue (MCFP technique) for resection of oral mucosa. Br J Oral Maxillofac Surg 2012;50:e43-e44.

20. Shinozaki T, Hayashi R, Ebihara M, Miyazaki M, Tomioka T. Mucosal defect repair with a polyglycolic acid sheet. Jpn J Clin Oncol 2013;43:3336.

21. Yano T, Haro A, Shikada Y, Okamoto T, Maruyama R, Maehara Y. A unique method for repairing intraoperative pulmonary air leakage with both polyglycolic acid sheets and fibrin glue. World J Surg 2012;36:463467.

22. Rogosnitzky M, Danks R, Kardash E. Therapeutic potential of tranilast, an anti-allergy drug, in proliferative disorders. Anticancer Res 2012;32:2471-2478

23. Carrico TJ, Mehrhof AI Jr, Cohen IK. Biology of wound healing. Surg Clin North Am 1984;64:721-733. 